\title{
2010 SOIL CHARACTERIZATION REPORT FOR THE AREA 11 EXPLOSIVE ORDNANCE DISPOSAL UNIT NEVADA TEST SITE
}

\author{
Prepared for \\ U.S. Department of Energy \\ National Nuclear Security Administration \\ Nevada Site Office

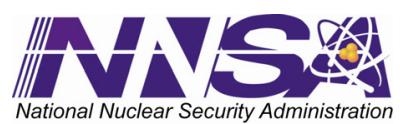 \\ National Nuclear Security Administration
}

Prepared by

National Security Technologies, LLC

National Security Technologies LLc

Vision - Service - Partnership

February 2010 


\section{DISCLAIMER}

Reference herein to any specific commercial product, process, or service by trade name, trademark, manufacturer, or otherwise, does not necessarily constitute or imply its

endorsement, recommendation, or favoring by the United States Government or any agency thereof.

Available for sale to the public from:

U.S. Department of Commerce

National Technical Information Service

5301 Shawnee Road

Alexandria, VA 22312

Telephone: $800-553-6847$

Fax: 703-605-6900

E-mail: orders@ntis.gov

Online ordering: http://www.ntis.gov/help/ordermethods.aspx

Available electronically at http://www.osti.gov/bridge

Available for a processing fee to the U.S. Department of Energy and its contractors, in paper, from:

U.S. Department of Energy

Office of Scientific and Technical Information

P.O. Box 62

Oak Ridge, TN 37831-0062

Telephone: 865-576-8401

Fax: 865-576-5728

E-mail: reports@adonis.osti.gov 


\section{TABLE OF CONTENTS}

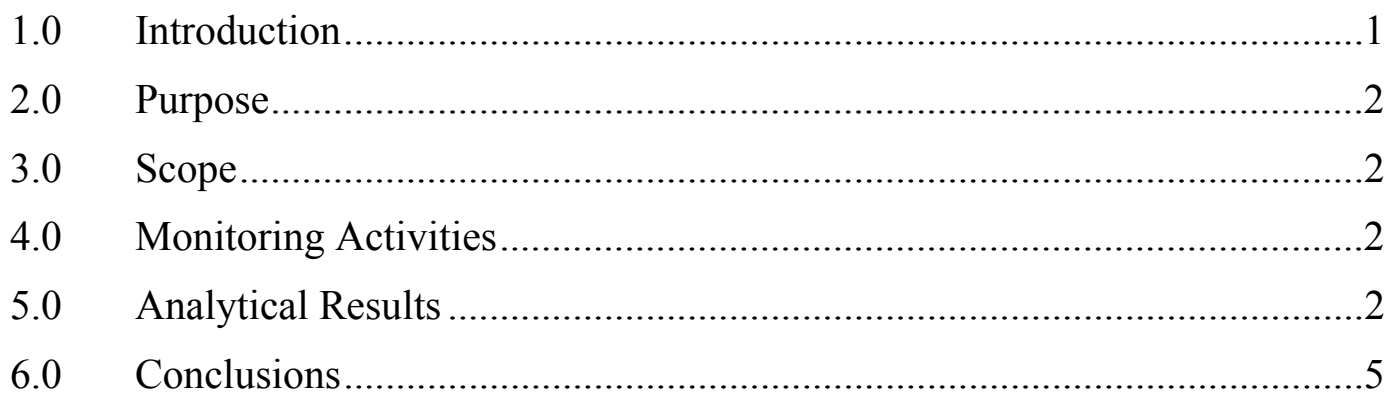

\section{LIST OF FIGURES}

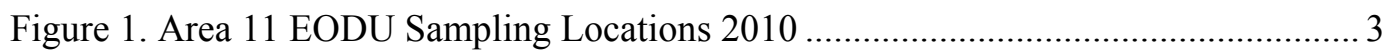

\section{LIST OF TABLES}

Table 1. Area 11 EODU Analytical Results 4 


\section{ACRONYMS AND ABBREVIATIONS}

CFR Code of Federal Regulations

DOE/NV U.S. Department of Energy, Nevada Operations Office

EMS Environmental Management System

EODU Explosive Ordnance Disposal Unit

EPA Environmental Protection Agency

HMX Cyclotetramethylenetetranitramine

NDEP Nevada Division of Environmental Protection

NTS Nevada Test Site

PETN Pentaerythritol Tetranitrate

RCRA Resource Conservation and Recovery Act

RDX Cyclotrimethylenetrinitramine

TCLP Toxicity Characterization Leaching Procedure

TNT Trinitrotoluene 


\subsection{Introduction}

The Explosive Ordnance Disposal Unit (EODU), located in Area 11 of the Nevada Test Site (NTS), is an explosive detonation unit for the treatment of onsite generated waste explosives that are hazardous waste as defined under Title 40 Code of Federal Regulations (CFR) Part 261.23(a) (6), (7), and (8), and also 40 CFR 265.382.

The EODU began operations on May 12, 1965, for the open burning and detonation of waste explosives. In the 1980s open burning of waste explosives was discontinued. In May 1995, the Nevada Division of Environmental Protection (NDEP) issued a Resource Conservation and Recovery Act (RCRA) Permit (NEV HW0009) to the U.S. Department of Energy, Nevada Operations Office (DOE/NV) for the thermal treatment of waste explosives at the EODU. This unit is currently operated according to the RCRA Part B Permit (NEV HW0021, November 2005), the NTS Class II Air Quality Operating Permit (AP9711-2557), U.S. Department of Energy orders, and other applicable federal and state regulations.

The controlled area containing the unit includes approximately 8.1 hectares (20 acres) of land located in the Massachusetts Mountains, between Frenchman Flat and Yucca Flat. The EODU consists of three graded areas including a detonation pit surrounded by an earthen pad approximately 20 meters (61 feet) by 30 meters ( 98 feet); a storage magazine, which is also used as a satellite accumulation area for waste explosives; and a firing point that is located approximately 1.4 kilometers ( 0.86 miles) west of the detonation pad on the access road.

Most of the explosives detonated at the EODU are water-gel (Pentaerythritol Tetranitrate [PETN]) and slurry explosives. Other explosives detonated include Trinitrotoluene (TNT), Cyclotrimethylenetrinitramine (RDX) pellets, cyclotetramethylenetetranitramine (HMX), small arms ammunition, solid rocket propellant, and black powder. Explosive waste is generated by tunneling and construction activities, high explosives testing, experimental explosives testing, special projects, and the security force firing range.

No radioactive or radioactive-contaminated materials are accepted or detonated at the EODU. The unit has an annual operations capacity of 1,870 kilograms $(4,123$ pounds) of waste explosive. The process design capacity of the EODU is approximately 45.4 kilograms/hour (100 pounds/hour).

In 1994, both NDEP and DOE/NV agreed that soil samples should be taken from the detonation pit to determine the impact to soils from historic operations. In January 1995, DOE/NV submitted the first characterization report. This characterization indicated the presence of Toxicity Characterization Leaching Procedure (TCLP) metals and explosive residues. The RCRA Permit issued in May 1995 required that this characterization be repeated on a five-year cycle. 


\subsection{Purpose}

This soil characterization report summarizes sampling activities and analytical results, provides copies of laboratory data reports, and meets the requirements of Section IV.G.2 of the Permit (NEV HW0021, November 2005) and Sections P.3.d.7.b and P.3.n of the Permit Application (DOE/NV--1053-VOL 4, May 2005).

\subsection{Scope}

The objective of soil characterization is to attempt to establish baseline conditions and to determine if the continued operations of the EODU are adversely impacting the environment adjacent to the unit. The characterization data may also provide supporting data for the eventual closure of the unit. Four areas were identified for sampling: (1) the detonation pad, (2) the detonation pit, (3) the area designated as downwind, and (4) the area designated as background.

\subsection{Monitoring Activities}

The soil sampling was conducted on November 3, 2009. Personnel conducting the sampling were briefed on unit conditions and operations safety by the EODU Operations Supervisor prior to entering the unit. Sampling locations are noted in Figure 1. The background location selected was approximately 31 meters (100 feet) northwest of the detonation pit.

The surface and subsurface samples were collected from each location in a systematic manner. After surface gravel and debris were removed, clean stainless steel trowels were used to gather the surface sample from approximately 0 to 15 centimeters ( $0-6$ inches) below the surface. Each subsurface sample was collected from approximately 15 to 30 centimeters (6-12 inches) below the surface in the same manner as the surface sample. All samples were immediately containerized, labeled, and placed in a cooler with ice. Chain of custody procedures were followed as prescribed by Environmental Protection Agency (EPA) Publication SW-846.

Samples from each location were analyzed for the following constituents using EPA-approved methods. The background location was not required to be sampled for explosives residue.

Constituent

Explosive Residues (nitroglycerin)

PETN, RDX, HMX, TNT

TCLP Metals

Ignitability (flashpoint)

Nitrates

Total Petroleum Hydrocarbon (diesel range)
Analytical Method

8332

8330

6010

1010

300.0

$8015 \mathrm{M}$

\subsection{Analytical Results}

A summary of the sample results are provided in Table 1. Variations in the sample results from previous sampling events are indicative of re-grading of the detonation pad every one to two years. Non-detect concentrations recorded on laboratory documentation indicate the analytical method's reporting limit. 


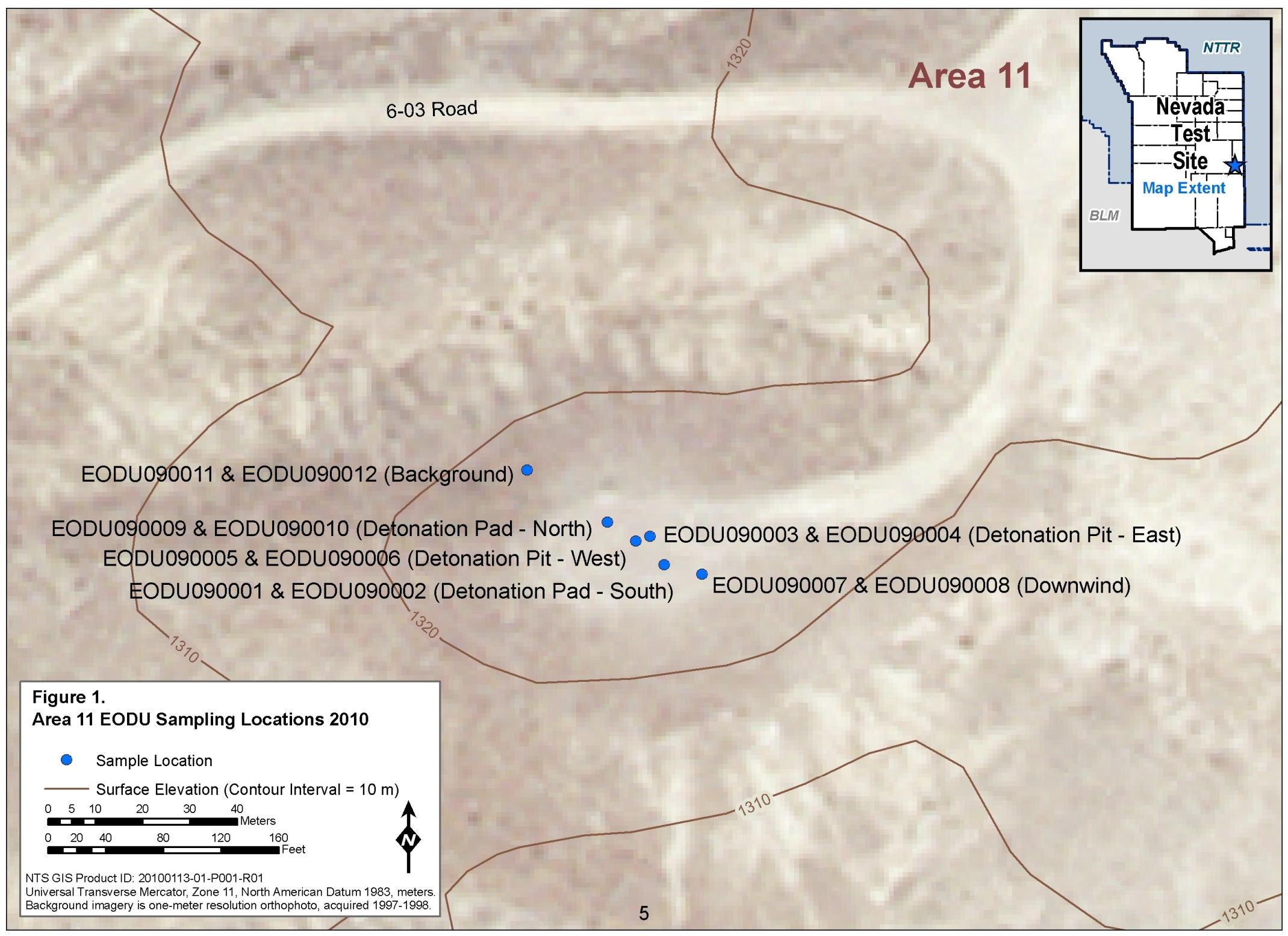

Figure 1. Area 11 EODU Sampling Locations 2010 
Table 1. Area 11 EODU Analytical Results

Sample Date: November 3, 2009

\begin{tabular}{|c|c|c|c|c|c|c|c|c|c|c|c|c|c|c|}
\hline Method & Analyte & Unit & \multicolumn{12}{|c|}{ Sample Concentrations } \\
\hline & & & \multicolumn{2}{|c|}{ Background } & \multicolumn{2}{|c|}{ Downwind } & \multicolumn{2}{|c|}{ Detonation Pad (North) } & \multicolumn{2}{|c|}{$\begin{array}{l}\text { Detonation Pad } \\
\quad \text { (South) }\end{array}$} & \multicolumn{2}{|c|}{ Detonation Pit (West) } & \multicolumn{2}{|c|}{ Detonation Pit (East) } \\
\hline & & & Surface & Subsurface & Surface & Subsurface & Surface & Subsurface & Surface & Subsurface & Surface & Subsurface & Surface & Subsurface \\
\hline \multicolumn{3}{|c|}{ Sample No: EODU0400\#\# } & 11 & 12 & 7 & 8 & 9 & 10 & 1 & 2 & 5 & 6 & 3 & 4 \\
\hline \multirow[t]{4}{*}{8330} & $\mathrm{HMX}$ & ug/kg & NS & NS & ND & ND & 1,280 & 915 & ND & ND & 732 & 1,100 & 808 & 628 \\
\hline & RDX & $\mathrm{ug} / \mathrm{kg}$ & NS & NS & ND & ND & 10,700 & 5,580 & ND & ND & 3,670 & 5,000 & 2,140 & 2,450 \\
\hline & PETN & ug/kg & NS & NS & ND & ND & ND & ND & ND & ND & ND & ND & 12,300 & ND \\
\hline & TNT & $\mathrm{ug} / \mathrm{kg}$ & NS & NS & ND & ND & ND & ND & ND & ND & $\mathrm{ND}(J)$ & $\mathrm{ND}(J)$ & 370 & ND \\
\hline 8332 & Nitroglycerin & $\mathrm{ug} / \mathrm{kg}$ & NS & NS & ND & ND & ND & ND & ND & ND & ND & 790 & 7,950 & 3,240 \\
\hline $8015 \mathrm{M}$ & $\begin{array}{c}\text { TPH } \\
\text { (Diesel) }\end{array}$ & $\mathrm{mg} / \mathrm{kg}$ & ND & ND & ND & ND & ND & ND & ND & ND & $\mathrm{ND}(\mathrm{J})$ & $\mathrm{ND}(\mathrm{J})$ & 6,550 & ND $(J)$ \\
\hline \multirow[t]{8}{*}{6010} & Arsenic & ug/L & ND & ND & $32.9(\mathrm{JD})$ & $32.1(\mathrm{JD})$ & $68(J D)$ & 51.3(JD) & 78.7(JD) & $110(D)$ & 83.9(JD) & 84.4(JD) & 466(JD) & 38.3(JD) \\
\hline & Barium & ug/L & 225(D) & 215(D) & 125(D) & 224(D) & $128(D)$ & 93.8(D) & $25(D)$ & $32(D)$ & $110(D)$ & $110(D)$ & $126(D)$ & 114(D) \\
\hline & Cadmium & ug/L & ND & ND & ND & ND & 3.4(JD) & ND & ND & ND & ND & 10.7(JD) & 4.2(JD) & 7.3(JD) \\
\hline & Chromium & ug/L & ND & ND & ND & ND & ND & ND & ND & ND & 8.1(JD) & 8.5(JD) & ND & 7.7(JD) \\
\hline & Lead & ug/L & 42.7(D) & ND & ND & ND & 103(D) & $364(D)$ & ND & ND & 95.5(D) & 179(D) & $1,100(D)$ & $1,580(D)$ \\
\hline & Mercury & ug/L & ND & ND & ND & $0.08(J)$ & ND & ND & ND & ND & ND & 34.2(D) & $31(J D)$ & ND \\
\hline & Selenium & ug/L & ND & ND & ND & ND & $53.8(J D)$ & 36.2(JD) & ND & ND & ND & ND & ND & ND \\
\hline & Silver & ug/L & ND & ND & ND & ND & ND & ND & ND & ND & ND & ND & ND & ND \\
\hline 1010 & Ignitability & ${ }^{\circ} \mathrm{F}$ & \multicolumn{12}{|c|}{ All samples were heated to $200^{\circ} \mathrm{F}$ and did not ignite. } \\
\hline 300.0 & Nitrates & $\mathrm{mg} / \mathrm{kg}$ & 12.3 & 4.2 & 14.9 & 10.3 & 747 & 320 & 10.3 & 9.1 & 122 & 96.9 & 57.9 & 35.1 \\
\hline
\end{tabular}

NS - Not Sampled

ND - None Detected

$\mathrm{J}$ - Present below detection limit (estimated value)

\section{D - Identified as a secondary dilution factor}

Notes - Surface/subsurface samples from locations other than "Background" were analyzed for explosive residues, which resulted in two sample designations for these locations. 


\subsection{Conclusions}

In accordance with Section P.3.d.7.b.3 of Volume 4 of the Permit Application, the data has been organized and evaluated in terms of the following:

1. The Presence of Contaminated Soils on Site - Soil contamination has been identified in the four sampling events (1995, 2000, 2005, and 2009).

2. The Chemical Nature of Identified Contaminants in the Soil - Explosive residues, TCLP metals, nitrates, and nitroglycerin were detected in the samples. The background sample contained barium and lead, while arsenic and chromium (detected in 2005) were absent. Cadmium was detected in fewer samples and at lower levels than in 2005. The detonation pit samples as a group exhibited the highest concentrations of explosive residue as expected. Variability between previous sampling events and the 2009 results can be attributed to re-grading of the detonation pad, a normal maintenance activity.

3. Physical Properties of the Shallow Subsurface Material in the Unit Vicinity - The shallow subsurface material is colluvium.

4. The Need for Additional Characterization of the Site - Additional characterization of the site is not needed at this time. Sampling under the Part B Permit will continue on a five-year schedule until closure. 